Review

\title{
Daily sit-to-stands performed by adults: a systematic review
}

\author{
RichaRd W BOHANNON, PT, DPT, EdD ${ }^{1)}$ \\ 1) Department of Kinesiology, College of Agriculture, Health, and Natural Resources, University of \\ Connecticut: Storrs, CT 06269, USA
}

\begin{abstract}
Purpose] The sit-to-stand (STS) maneuver is a component of everyday mobility. The purpose of this review was to summarize the number of daily STSs performed by adults with or without pathology. [Methods] Four bibliographic databases were searched followed by a consultation with experts and a search by hand to locate articles reporting daily STSs. Information on measurement procedures, tested populations, and daily STSs was extracted. Methodological quality was rated. [Results] Ten articles were identified. The mean number of daily STSs ranged from 33 to 71 . The mean number was at least 45 for all groups except patients with congestive heart failure, residents of a hospital ward and one group of older adults. [Conclusion] Individuals performing fewer than 45 daily STSs may be experiencing a work deficit and benefit from additional intentional STS repetitions.

Key words: Mobility, Sit-to-stand, Chair-rise
\end{abstract}

(This article was submitted Jul. 28, 2014, and was accepted Oct. 1, 2014)

\section{INTRODUCTION}

The sit-to-stand (STS) transition is a fundamental aspect of mobility ${ }^{1)}$. The maneuver is relatively demanding from a neuromuscular perspective ${ }^{2)}$ and is affected negatively by age and pathology ${ }^{3-6)}$. It should not be surprising, therefore, that repeated STSs are a common component of exercise regimens directed at older adults and patients with stroke or other pathologies ${ }^{7-11)}$. Perspective as to how many STSs should be recommended for patients receiving physical therapy might be gained by knowing the number performed daily by apparently healthy adults and by patients with pathology. If individuals are performing a limited number of STSs over the course of a day, they may be experiencing a work deficit that could contribute further to strength impairments and activity limitations. This systematic review was conducted to determine what is known about the number of daily STSs performed by adults-both those who are healthy and those with pathology.

\section{METHODS}

To be included in this review, an article had to describe the number of daily ( 24 hours or waking day) STSs performed by adult humans. To identify potentially relevant articles, searches of PubMed (from 1950), Science Citation

Corresponding author. Richard W Bohannon (E-mail: richard. bohannon@uconn.edu)

C2015 The Society of Physical Therapy Science. Published by IPEC Inc. This is an open-access article distributed under the terms of the Creative Commons Attribution Non-Commercial No Derivatives (by-ncnd) License $<$ http://creativecommons.org/licenses/by-nc-nd/3.0/>.
Index (from 1994), Scopus (from 1996), and CINAHL (from 1981) were conducted on January 10, 2013. The search string for PubMed was: ("stand up" OR "standing up" OR "sit to stand" OR "chair rise" OR "chair rises") AND (monitor*[ti] OR "activity monitor" OR "activity monitors" OR "activity monitoring" OR frequency[ti] OR "Monitoring, Ambulatory"[MAJR] OR "ambulatory monitoring" OR "ambulatory monitor" OR "ambulatory monitors") NOT ("heart rate monitoring" OR "blood pressure monitoring" OR "fetal monitoring" OR "memory monitoring"). The search strings for the other databases were similar but adapted as necessary to database specifics. RefWorks was used to consolidate the searches and eliminate duplicates. This process resulted in the identification of 177 potentially relevant unique articles. A search by hand and consultation with 2 experts (Thorlene Egerton and Phillipa Dall) yielded 7 additional articles. After an examination of the full text of these articles, 174 were excluded by the author because they did not report daily STSs. The remaining 10 relevant articles were abstracted for information on: 1) the procedure used to document daily STSs, 2) the population studied (country of residence, residence or health status, age, and number), and 3 ) the mean and standard deviation of the number of daily STSs performed. Confidence intervals (95\%) for daily STSs were calculated using the mean, standard deviation, and sample size for each population. If an article described STSs performed in the context of an intervention, only information from baseline or from the control group was abstracted. Because of the heterogeneity of methods and samples, statistical aggregation and analysis were not conducted. The quality of the 10 included articles was rated using a checklist adapted from applicable items from the Hagströmer-Bowles Physical Activity/Sedentary Behavior Questionnaire Checklist (HBQC) checklist ${ }^{12}$. 


\section{RESULTS}

The 10 identified articles are summarized in Table $1^{13-22)}$. In all but one study, an accelerometer-based activity monitor (most often the activePAL) attached to the anterior thigh(s) and/or chest was used to quantify STS transitions. In the aberrant study, a tally counter was employed ${ }^{13)}$. That study required the individuals being monitored to "click" the

Table 1. Summary of the 10 studies reporting accumulated daily sit-to-stands (STSs)

\begin{tabular}{|c|c|c|c|}
\hline Study & Measurement Procedure & Population & $\begin{array}{c}\text { Daily STSs } \\
\text { Mean } \pm \text { SD }(95 \% \mathrm{CI})\end{array}$ \\
\hline $\begin{array}{l}\text { Bohannon } \\
\text { et al. }{ }^{13)}\end{array}$ & $\begin{array}{l}\text { Talley counter used by participants } \\
\text { for } 7 \text { days }\end{array}$ & $\begin{array}{l}\text { United States } \\
\text { Community-dwelling adults (51 } \pm 21 \text { years): } \\
\qquad \mathrm{n}=96\end{array}$ & $\begin{array}{l}46 \pm 17(43-49) \\
\text { Significantly more on weekdays than } \\
\text { weekend days. }\end{array}$ \\
\hline $\begin{array}{l}\text { Dall and } \\
\text { Kerr }^{14)}\end{array}$ & $\begin{array}{l}\text { ActivePAL attached to partici- } \\
\text { pants' thighs for } 3 \text { or } 7 \text { days }\end{array}$ & $\begin{array}{l}\text { Scotland } \\
\text { Community-dwelling adults (40 } \pm 9 \text { years): } \\
\mathrm{n}=140\end{array}$ & $\begin{array}{l}\qquad 60 \pm 22(57-64) \\
\text { Significantly more by indoor sed- } \\
\text { entary workers than outdoor active } \\
\text { workers. Significantly more during } \\
\text { working days than nonworking days. }\end{array}$ \\
\hline \multirow[t]{3}{*}{$\begin{array}{l}\text { Grant } \\
\text { et al. }{ }^{15)}\end{array}$} & $\begin{array}{l}\text { ActivePAL attached to partici- } \\
\text { pants' thighs for up to } 7 \text { days }\end{array}$ & $\begin{array}{l}\text { Scotland } \\
\text { Community-dwelling older adults }(74 \pm 5 \text { years }) \text { : } \\
n=20\end{array}$ & $71 \pm 25(59-83)$ \\
\hline & & $\begin{array}{l}\text { Scotland } \\
\text { Day hospital attendees ( } 75 \pm 8 \text { years): } n=20\end{array}$ & $57 \pm 23(46-68)$ \\
\hline & & $\begin{array}{l}\text { Scotland } \\
\text { Hospital ward residents ( } 81 \pm 6 \text { years): } n=30\end{array}$ & $36 \pm 16(30-42)$ \\
\hline $\begin{array}{l}\text { deBruin } \\
\text { et al. }{ }^{16)}\end{array}$ & $\begin{array}{l}\text { Custom device attached to partici- } \\
\text { pants' sternum for } 2 \text { consecutive } \\
\text { weekdays during } 1 \text { week and } 1 \text { of } \\
\text { the same days the following week }\end{array}$ & $\begin{array}{l}\text { Switzerland } \\
\text { Residential care occupants (88 } \pm 2 \text { years): } \\
n=11\end{array}$ & $\begin{array}{l}60 \pm 23(47-73)[\text { week 1] } \\
56 \pm 17(45-67)[\text { week 2] }\end{array}$ \\
\hline $\begin{array}{l}\text { Van den } \\
\text { Berg-Emons } \\
\text { et al. }{ }^{17)}\end{array}$ & $\begin{array}{l}\text { Activity monitor attached to par- } \\
\text { ticipants' sternum and thighs for } 2 \\
\text { consecutive weekdays }\end{array}$ & $\begin{array}{l}\text { The Netherlands } \\
\text { Individuals without congestive heart failure or } \\
\text { mobility limitations ( } 65 \pm 4 \text { years }): n=5\end{array}$ & $54 \pm 19(30-78)$ \\
\hline \multirow{5}{*}{$\begin{array}{l}\text { De Groot } \\
\text { et al. }{ }^{18)}\end{array}$} & & $\begin{array}{l}\text { The Netherlands } \\
\text { Patients with congestive heart failure } \\
(64 \pm 5 \text { years }): n=5\end{array}$ & $33 \pm 12(18-48)$ \\
\hline & $\begin{array}{l}\text { Activity monitor attached to par- } \\
\text { ticipants' sternum and thighs for } 2 \\
\text { consecutive days }\end{array}$ & $\begin{array}{l}\text { The Netherlands } \\
\text { Healthy controls matched with patients sched- } \\
\text { uled for hip arthroplasty ( } 59 \pm 12 \text { years): } n=34\end{array}$ & $61 \pm 23(53-69)$ \\
\hline & & $\begin{array}{l}\text { The Netherlands } \\
\text { Healthy controls matched with patients sched- } \\
\text { uled for knee arthroplasty ( } 60 \pm 11 \text { years): } n=37\end{array}$ & $61 \pm 23(54-68)$ \\
\hline & & $\begin{array}{l}\text { The Netherlands } \\
\text { Patients with osteoarthritis scheduled for hip } \\
\text { arthroplasty ( } 60 \pm 13 \text { years): } \mathrm{n}=34\end{array}$ & $50 \pm 14(45-55)$ \\
\hline & & $\begin{array}{l}\text { The Netherlands } \\
\text { Patients with osteoarthritis scheduled for knee } \\
\text { arthroplasty }(61 \pm 10 \text { years }): \mathrm{n}=37\end{array}$ & $47 \pm 14(42-52)$ \\
\hline \multirow[t]{2}{*}{$\begin{array}{l}\text { Egerton and } \\
\text { Brauer }^{19)}\end{array}$} & $\begin{array}{l}\text { ActivePAL attached to participants' } \\
\text { thighs for } 3 \text { consecutive days }\end{array}$ & $\begin{array}{l}\qquad \text { Australia } \\
\text { Individuals living at home ( } 71 \pm 4 \text { years }): n=15\end{array}$ & $65 \pm 17(56-74)$ \\
\hline & & $\begin{array}{c}\text { Australia } \\
\text { Individuals living in aged care facilities } \\
(87 \pm 7 \text { years }): \mathrm{n}=16\end{array}$ & $47 \pm 27(33-61)$ \\
\hline $\begin{array}{l}\text { Lord } \\
\text { et al. }{ }^{20)}\end{array}$ & $\begin{array}{l}\text { ActivePAL attached to partici- } \\
\text { pants' thighs for } 7 \text { days }\end{array}$ & $\begin{array}{l}\text { Australia } \\
\text { Individuals living independently in community } \\
(79 \pm 5 \text { years }): n=56\end{array}$ & $39 \pm 11(36-42)$ \\
\hline $\begin{array}{l}\text { Maddocks } \\
\text { and } \\
\text { Wilcock }^{21)}\end{array}$ & $\begin{array}{l}\text { ActivePAL attached to participants' } \\
\text { thighs for } 6 \text { days ( } 2 \text { weekend) }\end{array}$ & $\begin{array}{l}\text { England } \\
\text { Patients with end-stage thoracic cancer } \\
(66 \pm 9 \text { years }): \mathrm{n}=84\end{array}$ & $45 \pm 17(41-49)$ \\
\hline $\begin{array}{l}\text { Ryan } \\
\text { et al. }{ }^{22)}\end{array}$ & $\begin{array}{l}\text { ActivePAL attached to thigh for } 7 \\
\text { days }\end{array}$ & $\begin{array}{l}\text { Scotland } \\
\text { Patients with low back pain (45 } \pm 11 \text { years): } \mathrm{n}= \\
38\end{array}$ & $59 \pm 16(54-64)$ \\
\hline
\end{tabular}


counter every time they completed a STS from the surface of a standard chair height or below. The number of days during which STSs were monitored ranged from 2 to 7 . Participants in studies reporting daily STS repetitions were diverse. Most participants were community-dwelling/healthy individuals, but some were residents under hospital, rehabilitation or residential care, and some had health issues. Among the latter were patients with congestive heart failure, cancer, osteoarthritis, or low back pain. Most monitored participants were older adults. The total number of participants monitored was 678 , with the number in any one monitored group ranging from 5 to 140 .

The mean number of daily STSs varied from 33 to 71 . The mean number of daily STSs was at least 45 for all groups except for one group of community-dwelling older adults $(\text { mean }=39)^{20)}$, patients with congestive heart failure $(\text { mean }=33)^{17)}$, and hospital ward residents $(\text { mean }=36)^{15)}$. Among community-dwelling adults, the number of STSs was greater on weekdays or working days than on weekend days or nonworking days ${ }^{13}, 14$ ).

Total quality scores on the adapted HBQC ranged from 6 to 12 out of 15 (Table 2). The most common impediments to a high quality score were a failure to report confidence intervals, uncertainty as to the representativeness of the sample, and a lack of blinding of research staff.

\section{DISCUSSION}

The STS maneuver is a key element of everyday activity for most people. However, unlike the number of ambulatory steps accumulated daily ${ }^{23}$, the number of STSs performed daily has received much less attention. This review shows, nevertheless, that there is useful information regarding daily STSs to guide physical therapy practice. The literature suggests it is reasonable to expect all but perhaps some older community-dwelling individuals (including those with arthritis, cancer, and low back pain) to perform at least 45 STSs per day ${ }^{13-15,17-22)}$. The literature also suggests that it is

Table 2. Assessment of methodological quality using a modification of the Hagströmer et al. Checklist for the 10 included studies

\begin{tabular}{|c|c|c|c|c|c|c|c|c|c|c|}
\hline Item & $\begin{array}{l}\text { Bohannon } \\
\text { et al. }{ }^{13)}\end{array}$ & $\begin{array}{l}\text { Dall } \\
\text { and } \\
\text { Kerr }^{14)}\end{array}$ & $\begin{array}{l}\text { Grant } \\
\text { et al. }{ }^{15)}\end{array}$ & $\begin{array}{l}\text { De Bruin } \\
\text { et al. }{ }^{16)}\end{array}$ & $\begin{array}{l}\text { Van den } \\
\text { Berg- } \\
\text { Emons } \\
\text { et al. }{ }^{17)}\end{array}$ & $\begin{array}{c}\text { De Groot } \\
\text { et al. }{ }^{18)}\end{array}$ & $\begin{array}{l}\text { Egerton } \\
\text { and } \\
\text { Brauer }^{19)}\end{array}$ & $\begin{array}{l}\text { Lord } \\
\text { et al. }{ }^{20)}\end{array}$ & $\begin{array}{l}\text { Maddocks } \\
\quad \text { and } \\
\text { Wilcock }^{21)}\end{array}$ & $\begin{array}{l}\text { Ryan } \\
\text { et al. }{ }^{22)}\end{array}$ \\
\hline $\begin{array}{l}\text { 1. Objective clearly } \\
\text { described }\end{array}$ & 1 & 1 & 1 & 1 & 1 & 1 & 1 & 1 & 1 & 1 \\
\hline $\begin{array}{l}\text { 2. Activity clearly } \\
\text { described }\end{array}$ & 1 & 1 & 1 & 1 & 1 & 1 & 1 & 1 & 1 & 1 \\
\hline $\begin{array}{l}\text { 3. Participant character- } \\
\text { istics clearly described }\end{array}$ & 1 & 1 & 1 & 1 & 1 & 1 & 0 & 1 & 1 & 1 \\
\hline $\begin{array}{l}\text { 5. Principal confounders } \\
\text { clearly described }\end{array}$ & 1 & 1 & 1 & 1 & 1 & 1 & 0 & 1 & 1 & 1 \\
\hline $\begin{array}{l}\text { 6. Measurements clearly } \\
\text { described }\end{array}$ & 1 & 1 & 1 & 1 & 1 & 1 & 1 & 1 & 1 & 1 \\
\hline $\begin{array}{l}\text { 7. Data reduction clearly } \\
\text { described }\end{array}$ & 1 & 1 & 1 & 1 & 1 & 1 & 1 & 1 & 1 & 1 \\
\hline $\begin{array}{l}\text { 8. Characteristics of } \\
\text { participants with } \\
\text { excluded data noted }\end{array}$ & 1 & 0 & 1 & 1 & 1 & 0 & 0 & 0 & 1 & 1 \\
\hline $\begin{array}{l}\text { 9. Variability of activity } \\
\text { data described }\end{array}$ & 1 & 1 & 1 & 1 & 1 & 1 & 1 & 1 & 1 & 1 \\
\hline $\begin{array}{l}\text { 10. Confidence intervals } \\
\text { reported }\end{array}$ & 0 & 0 & 1 & 0 & 0 & 0 & 0 & 0 & 0 & 0 \\
\hline $\begin{array}{l}\text { 11. Representativeness of } \\
\text { sample delineated }\end{array}$ & 0 & 0 & 0 & 0 & 1 & 0 & 0 & 0 & 0 & 0 \\
\hline $\begin{array}{l}\text { 13. Research design compa- } \\
\text { rable to other studies }\end{array}$ & 0 & 1 & 1 & 1 & 1 & 1 & 1 & 1 & 1 & 1 \\
\hline $\begin{array}{l}\text { 14. Alteration in physical } \\
\text { activity minimized }\end{array}$ & 0 & 0 & 0 & 0 & 1 & 0 & 0 & 0 & 0 & 0 \\
\hline 15. Research staff blinded & 0 & 0 & 0 & 0 & 0 & 0 & 0 & 0 & 0 & 0 \\
\hline $\begin{array}{l}\text { 18. Compliance with } \\
\text { protocol acceptable }\end{array}$ & 0 & 0 & 0 & 1 & 0 & 0 & 0 & 0 & 0 & 0 \\
\hline $\begin{array}{l}\text { 19. Reproducibility of } \\
\text { measure reported }\end{array}$ & 1 & 0 & 0 & 1 & 1 & 0 & 0 & 0 & 0 & 0 \\
\hline Total & 9 & 8 & 10 & 11 & 12 & 8 & 6 & 8 & 9 & 9 \\
\hline
\end{tabular}

$1=$ yes, addressed; $0=$ not addressed or unable to determine 
reasonable to expect fewer daily STS from adults with some pathologies.

Patients performing a limited number of STSs, relative to a comparable patient group or healthy adults, might be considered to be experiencing a work deficit that may contribute to their muscle weakness and activity limitations. They may benefit, therefore, from educational and procedural interventions focused on intentionally increasing STS activity. Studies of patients with stroke suggest this to be the case. Asberg reported some benefits for patients engaged in additional STS training the first 2 weeks after stroke ${ }^{24)}$. Tung et al. also reported positive outcomes for patients receiving additional STS training in a rehabilitation center ${ }^{25}$. Boyn et al. described 2 patients more than 2 years post stroke who were initially dependent on assistance to achieve STS. They achieved independence in STS after performing more than 750 STSs over $8-11$ sessions $^{10)}$.

This study had several limitations. First, although the search was thorough, only 10 studies were found, and their heterogeneous samples precluded mathematical consolidation. A larger population-based study will need to be completed if valid normative values for daily STSs are to be determined. Second, a single individual made decisions as to a study's inclusion and performed all abstracting of article content and quality assessments. Therefore, testing agreement with another rater is not described. Third, the HBQC was designed for assessing articles describing self-report rather than performance-based measures. Nevertheless, the instrument's focus is on physical activity. This emphasis was judged to render the instrument a better choice for quality rating than more generic instruments. Fourth, all of the studies included were quite deficient in quality on the basis of the checklist employed. Higher quality studies may yield different results.

In conclusion, it appears on average that the STS maneuver is completed at least 45 times per day by most community-dwelling individuals. The summary of 10 studies provided herein might serve as a basis for exercise goals aimed at increasing STS activity among individuals with fewer daily STSs.

\section{ACKNOWLEDGEMENT}

The invaluable assistance of Jill Livingston in the database searches is gratefully acknowledged.

\section{REFERENCES}

1) International Classification of Functioning: Disability and Health (Short Version). Chapter 4. World Health Organization, Geneva, 2001.

2) Hortobágyi $\mathrm{T}$, Mizelle $\mathrm{C}$, Beam $\mathrm{S}$, et al.: Old adults perform activities of daily living near their maximal capabilities. J Gerontol A Biol Sci Med Sci, 2003, 58: M453-M460. [Medline] [CrossRef]

3) Weiner DK, Long R, Hughes MA, et al.: When older adults face the chairrise challenge. A study of chair height availability and height-modified chair-rise performance in the elderly. J Am Geriatr Soc, 1993, 41: 6-10. [Medline]

4) Bohannon RW, Shove ME, Barreca SR, et al.: Five-repetition sit-to-stand test performance by community-dwelling adults: A preliminary investigation of times, determinants, and relationship with self-reported physical performance. Isokinet Exerc Sci, 2007, 15: 77-81.

5) Brodin E, Ljungman S, Sunnerhagen KS: Rising from a chair: a simple screening test for physical function in predialysis patients. Scand J Urol Nephrol, 2008, 42: 293-300. [Medline] [CrossRef]

6) Janssen W, Bussmann J, Selles R, et al.: Recovery of the sit-to-stand movement after stroke: a longitudinal cohort study. Neurorehabil Neural Repair, 2010, 24: 763-769. [Medline] [CrossRef]

7) Alexander NB, Galecki AT, Grenier ML, et al.: Task-specific resistance training to improve the ability of activities of daily living-impaired older adults to rise from a bed and from a chair. J Am Geriatr Soc, 2001, 49: 1418-1427. [Medline] [CrossRef]

8) Rosie J, Taylor D: Sit-to-stand as home exercise for mobility-limited adults over 80 years of age - GrandStand System may keep you standing? Age Ageing, 2007, 36: 555-562. [Medline] [CrossRef]

9) Askim T, Indredavik B, Engen A, et al.: Physiotherapy after stroke: to what extent is task-oriented practice a part of conventional treatment after hospital discharge? Physiother Theory Pract, 2013, 29: 343-350. [Medline] [CrossRef]

10) Boyne P, Israel S, Dunning K: Speed-dependent body weight supported sit-to-stand training in chronic stroke: a case series. J Neurol Phys Ther, 2011, 35: 178-184. [Medline] [CrossRef]

11) Britton E, Harris N, Turton A: An exploratory randomized controlled trial of assisted practice for improving sit-to-stand in stroke patients in the hospital setting. Clin Rehabil, 2008, 22: 458-468. [Medline] [CrossRef]

12) Hagströmer M, Ainsworth BE, Kwak L, et al.: A checklist for evaluating the methodological quality of validation studies on self-report instruments for physical activity and sedentary behavior. J Phys Act Health, 2012, 9: S29-S36. [Medline]

13) Bohannon RW, Barreca SR, Shove ME, et al.: Documentation of daily sitto-stands performed by community-dwelling adults. Physiother Theory Pract, 2008, 24: 437-442. [Medline] [CrossRef]

14) Dall PM, Kerr A: Frequency of the sit to stand task: an observational study of free-living adults. Appl Ergon, 2010, 41: 58-61. [Medline] [CrossRef]

15) Grant PM, Dall PM, Kerr A: Daily and hourly frequency of the sit to stand movement in older adults: a comparison of day hospital, rehabilitation ward and community living groups. Aging Clin Exp Res, 2011, 23: 437444. [Medline] [CrossRef]

16) de Bruin ED, Najafi B, Murer K, et al.: Quantification of everyday motor function in a geriatric population. J Rehabil Res Dev, 2007, 44: 417-428. [Medline] [CrossRef]

17) van den Berg-Emons H, Bussmann J, Balk A, et al.: Level of activities associated with mobility during everyday life in patients with chronic congestive heart failure as measured with an "activity monitor". Phys Ther, 2001, 81: 1502-1511. [Medline]

18) de Groot IB, Bussmann JB, Stam HJ, et al.: Actual everyday physical activity in patients with end-stage hip or knee osteoarthritis compared with healthy controls. Osteoarthritis Cartilage, 2008, 16: 436-442. [Medline] [CrossRef]

19) Egerton $T$, Brauer SG: Temporal characteristics of habitual physical activity periods among older adults. J Phys Act Health, 2009, 6: 644-650. [Medline]

20) Lord S, Chastin SF, McInnes L, et al.: Exploring patterns of daily physical and sedentary behaviour in community-dwelling older adults. Age Ageing, 2011, 40: 205-210. [Medline] [CrossRef]

21) Maddocks M, Wilcock A: Exploring physical activity level in patients with thoracic cancer: implications for use as an outcome measure. Support Care Cancer, 2012, 20: 1113-1116. [Medline] [CrossRef]

22) Ryan CG, Gray H, Newton M, et al.: The convergent validity of free-living physical activity monitoring as an outcome measure of functional ability in people with chronic low back pain. J Back Musculo Rehab, 2008, 21: 137-142.

23) Bohannon RW: Number of pedometer-assessed steps taken per day by adults: a descriptive meta-analysis. Phys Ther, 2007, 87: 1642-1650. [Medline] [CrossRef]

24) Åsberg KH: Orthostatic tolerance training of stroke patients in general medical wards. An experimental study. Scand J Rehabil Med, 1989, 21: 179-185. [Medline]

25) Tung FL, Yang YR, Lee CC, et al.: Balance outcomes after additional sitto-stand training in subjects with stroke: a randomized controlled trial. Clin Rehabil, 2010, 24: 533-542. [Medline] [CrossRef] 